\title{
Allocation of Fishing Harvest Rights in Iceland and Norway - the Development since 1990
}

Helgi Gretarsson, Law Institute of the University of Iceland, Reykjavik

\begin{abstract}
Unlike most western countries, marine fisheries in Iceland and Norway is still of some national significance. For more than two decades now, the two countries have managed their fisheries with complicated quota systems. The main rules of these two systems are explained in the article. However, the main purpose of the article is to describe how harvest rights in the two countries have been allocated since 1990 .

In both countries the principle of grandfathering the harvest rights has prevailed, i.e., the initial allocation has protected the professional interest of those that have already participated in the fisheries. Despite this, rules on the matter have not been engraved in stone since they have been dynamic and contingent on various amendments by the legislature and government.

Basic rules on allocation have been stipulated in acts in Iceland, while in Norway they have mostly been based on regulations. Since harvest rights are transferable in Iceland, this, in principle, should make the harvest rights better protected than in Norway. However, when the matter is scrutinized, it becomes clear that the Icelandic parliament has in fact reallocated harvest rights on a recurrent basis.

In Norway, rules on allocation of harvest rights have been relatively stable. This can be partly explained by the fact that the most important stakeholders in the Norwegian fisheries have in practice had important say on how the harvest rights have been allocated.
\end{abstract}

\section{Keywords}

Fisheries management, allocation of harvest rights, comparative law, property rights and equality before the law.

\section{Introduction}

When some aspects of fisheries legislation of coastal states are analysed and compared, it has to borne in mind what kind of institutional structures have been set up to manage commercial fisheries. In this regard Iceland and Norway are feasible for comparison since they have strong centralised authority ${ }^{1}$ in the field, e.g., those holding legislative and executive power have legal authority to establish a fisheries 
management system applying to the entire area within the states' territorial waters and Exclusive Fisheries Zone (EFZ) or Exclusive Economic Zone (EEZ). ${ }^{2}$ From this institutional standpoint it is of some interest to describe and compare quota management of the Icelandic and Norwegian fisheries. Since this article's objective is to explain main rules on allocation of fishing harvest rights ${ }^{3}$ in the two countries from 1990 onwards, it is a contribution to this research area.

The justification for selecting this period is based on the occurrence of major policy events in both countries in 1990. Fundamental rules of the Icelandic quota system were enacted on basis of an act that was valid for indefinite period, while in Norway catches of the coastal fleet were for the first time subject to fishing permits and quotas. Both these events have had significant impact on legal and public discourse on fisheries management issues in the two countries.

As the title of the article indicates, its intention is to give a legal historical account of the subject but also elaborate on the main principles currently applying in the two quota management systems. Hence, the article should offer sufficient grounds to compare the main rules on allocation of harvest rights in the two countries even though many details ${ }^{4}$ will be omitted in order to make the text on this complicated issue relatively brief and clear. ${ }^{5}$

\section{Allocation of harvest rights in Icelandic fisheries}

\subsection{Exclusive fishing zone and economic and social background of commercial fisheries}

In the fall of 1975, the Icelandic EFZ was extended to 200 nautical miles, based on specified baseline points. ${ }^{6}$ This caused some disputes, but eventually foreign vessels more or less left the Icelandic EFZ at the end of 1976. Hence, it was not until 1977 that Icelandic parties first engaged in fisheries on Iceland's fishing grounds, almost exclusively. In 1979 Iceland's territorial waters were extended to 12 miles, and the country's EEZ was extended to 200 nautical miles. ${ }^{7}$

Commercial fishing has been a very important economic activity in Iceland for many centuries, as the country is surrounded by rich fishing grounds. In the $20^{\text {th }}$ century the fundament of Icelandic economy was based on professional fishing; for instance, in 1960-67 and 1979-87 fish products were, respectively, 91\% and 74\% of Iceland's commodity exports (Arnason, R. 1995, 38). Even though the share of the seafood industry in GDP has declined somewhat for the past two decades, "the seafood industry remains an important part of the Icelandic economy, with a direct contribution to GDP of approximately $11 \%$ and $39 \%$ of merchandise export value in 2010" (Islandsbanki Seafood Industry Team 2011, 15). In many regions in Iceland the seafood industry is an important job provider. Outside the capital area the industry accounts for approximately $11.9 \%$ of all jobs, compared to $1.4 \%$ within the area. In 2010 the industry provided about 8,600 jobs, approximately 5,600 less jobs than in 1991 (Islandsbanki Seafood Industry Team 2011, 15).

Until 1992 Icelanders mainly caught domestic fish stocks, but the importance of catching straddling fish stocks and fish stocks that are solely to be found beyond the 
Icelandic EEZ has increased considerably since then. In terms of value the products from demersal species is highest, but products from pelagic species come next (Islandsbanki Seafood Industry Team 2011, 20; Arnason, R. 1997, 73-74). For the last twenty years the total catch has varied from about 1 million metric tons (Mt.) to 2 million $\mathrm{Mt}$. (Islandsbanki Seafood Industry Team 2011, p. 20). Compared with Norway, Icelanders engage in fish farming in limited measure (Iversen, A. et al. 2011, 5).

Fisheries management issues in Iceland have been very politically controversial, and the quota system has for a long time been fiercely contested. This can partly explain why regulations regarding the system are dynamic, i.e., the complicated regulatory framework has been recurrently revised and amended. In this context one has to bear in mind that most of the basic substantive rules on fisheries management are stipulated in acts, not in regulations. This has the effect that Parliament (Althingi) provides for how harvest rights are allocated.

\subsection{Main rules of the Icelandic quota system}

In the spring of 1990, Act No. 38/1990 on Fisheries Management (FMA) ${ }^{8}$ was enacted and more than 40 amendments were made to the Act until the legislation was reenacted as Act No. 116/2006 on Fisheries Management (also abbreviated as FMA). FMA has provided for a fairly universal individual and transferable vessel quota system. The cornerstone of the system is the authority of the government (Ministry of Agriculture and Fisheries) to issue regulations on Total Allowable Catch (TAC) for individual marine stocks. The TAC is usually valid for one year ${ }^{9}$ and is decided after the government has obtained recommendations from the Marine Research Institute (MRI).

The original provisions of FMA provided that commercial fishing permits should be assigned to fishing vessels that existed in the country and had not been decommissioned permanently. No new fishing vessel could enter the fleet unless another vessel, of comparable effort capacity, was scrapped. This arrangement was changed following the 1998 judgement of the Supreme Court of Iceland in the Fishing Permit case. ${ }^{10}$ Under the current Articles 4 and 5 of FMA, the owners of registered fishing vessels can obtain general fishing permits for commercial purposes upon fulfilling specified conditions. ${ }^{11}$

When the FMA was promulgated in 1990, the legal concept of a quota share was established for the first time. In essence quota share of a vessel means a long-term percentage of the TAC, while catch quota means the exact figure in tons that a vessel is entitled to catch for a particular fishing year or season. ${ }^{12}$ Quota shares and catch quotas will be referred here as quota entitlements.

Since 1 January 1991, the arrangement of individual and transferable vessel quotas has been based on an act of indefinite period. Subject to certain conditions, quota entitlements are transferable. Despite many amendments to the act these attributes of quota entitlements have not been radically altered, and there is no doubt that these rights have monetary value.

It has been debated among legal scholars how these rights are protected under the 
property rights provision of the Icelandic Constitution ${ }^{13}$ and a comparable provision in the European Convention on Human Rights ${ }^{14}$. When evaluating these property rights issues, it has to be noted that lines 1 and 3 of Article 1 of the Fisheries Management Act declare, on the one hand, that exploitable marine stocks of the Icelandic fishing banks are the common property of the Icelandic nation, and, on the other, that the allocation of harvest rights provided for by the Act endows individual parties with neither rights of ownership nor irrevocable control over harvest rights. ${ }^{15}$

\subsection{Development of rules on allocation of harvest rights}

\subsubsection{The enactment of FMA}

During the 1980s the Icelandic fishing fleet effort capacity expanded, for example, 2702 fishing vessels were registered at the start of 1990, but there were 1736 at the start of 1984 (Gretarsson, H. 2010, 307). In retrospect one can say that the systems used to manage demersal fisheries in Iceland in the period 1977-1990 contributed to overfishing and poor economic performance of the fishing industry (Gretarsson, $\mathrm{H}$. 2010, 308-309; Arnason, R. and Runolfsson, B. 2001, 24; Runolfsson, B. 1999, 123; Arnason, R. 1997, 75-76; Arnason, R. 1995, 40).

The initial provisions of FMA provided that quota shares were to be divided between vessels having general fishing permits and fulfilling various other conditions. Simply put, it can be said that the allocation of quota shares was mostly based on the status of individual fishing vessel at the end of 1989 (Gretarsson, H. 2010, 310-311).

The allocation of quota shares for the demersal species of cod, haddock, saithe, redfish and Greenland halibut (at that time accounting normally for $70-80 \%$ of the total catch value) was based on the catch experience of individual fishing vessels in the period 1 November 1980 to 31 December 1989. This description is not very accurate, nevertheless, it is the simplest available without explaining complex rules on the allocation of demersal fishing rights for the period 1984-1990. ${ }^{16}$ For stocks other than demersal species, i.e., Icelandic capelin, Icelandic summer-spawning herring, inshore shrimp, lobster and scallop, the initial allocation of catch quotas in the early 1980s was more important (Gretarsson, H. 2011, 45). However, allocation of quota share in deep-sea shrimp was mostly based on how fishing opportunities were allocated initially in 1988 (Gretarsson, H. 2011, 45; Gretarsson, H. 2008, 155-161). To sum up: according to temporary provisions of the original FMA quota shares were allocated for five demersal stocks and six other stocks. This allocation was primarily based on the catch experience of individual vessels during a certain period prior to the initial enactment of FMA.

Under the original provisions of FMA, more than 2000 small boats obtained commercial fishing permits. This small-boat fleet was mainly divided into two: on one hand, a category of small boats that received quota shares and, on the other, book-andline boats, i.e. boats catching with hook-and line and were under 6 gross register tonnages (GRT). About 900 boats belonged to the former category and over 1100 to the latter. Small boats in the former group received, altogether, a $12.16 \%$ quota share in cod, $7.62 \%$ in haddock and $2.39 \%$ in saithe, while hook-and-line boats were 
authorised to fish in a fishing effort system until the fall of 1994, but if their total catches exceeded a specified limit, cf. table 1, the fleet should begin fishing on the basis of the general catch quota system. ${ }^{17}$

\subsubsection{Development since 1991}

Since 1 January 1991, nine demersal species have been added to the quota system that has been based on FMA. ${ }^{18}$ The division of these quota shares was based on three years' fishing experience prior to the initial setting of the TAC. ${ }^{19}$ On the basis of Act No. 151/1996 on Fishing beyond Iceland's Exclusive Fishing Zone, quota shares in several valuable exploitable marine stocks (straddling fish stocks or stocks caught only outside of the Icelandic EEZ) were divided between individual vessels. ${ }^{20}$ The main rule has been that quota shares for these species have been divided on the basis of fishing vessel owners' fishing experience for a six-year period, of which only the best three years in the period have been counted. ${ }^{21}$

Even though quota entitlements have since 1991 always been a key element in obtaining the right to conduct commercial fishing, they have not been the only basis for commercial fishing since distribution of the annual TAC of some important demersal stocks, such as cod, haddock, saithe and wolffish, has been subject to recurrent changes. This has been possible since a certain portion of the TAC has been distributed to the hook-and-line fleet and on the basis of so-called special allocations ${ }^{22}$. The effect of this arrangement has been that the quota share has not been as solid a proportion of the TAC as was anticipated when the FMA was originally enacted. ${ }^{23}$

In a nutshell one can say that FMA, has stipulated a three pillar system; (1) the general (big) individual and transferable vessel quota system, (2) the (small) hook-andline individual and transferable quota system and (3) special allocations. For the purpose of this article, a little more detail must be provided on how demersal catches of the hook-and-line fleet have been managed.

The hook-and-line fleet caught far more fish (especially cod) in the period 19911993 than was originally anticipated. Instead of moving the fleet to the general quota system (as was stipulated originally in par. 6 of temporary provision II of FMA), the fishing effort system for hook-and-line boats was maintained, cf. Act No. 87/199424. This management system for hook-and-line boats developed in a complex manner until 1998. In 1999-2004, a special quota share system for hook-and-line boats was established in several steps - the 'small quota system'.

The main rules of the hook-and-line catch quota system are, by and large, similar to the big quota system, except that it is necessary to fish with hook and/or handline in the small system, and hook-and-line quota entitlements cannot be transferred from the little system to the big one. As of 2002 the size criterion for hook-and-line boats has been up to 15 gross tonnages (GT) instead of being up to 6 GRT. When the allocation of a hook-and-line quota share to boats with a hook-and-line catch quota had more or less been completed in the fall of 2006, the share of the fleet of hook-andline boats in the main demersal species had increased considerably, compared to what was planned when FMA was originally enacted, cf. the following table: 
Table 1: The estimated quota share of hook-and-line boats on 1 January 1991 and the hook-and-line boats' quota share on 1 September $2006^{25}$

$\begin{array}{lcc}\text { Species } & \begin{array}{c}\text { Estimated quota share of } \\ \text { hook-and-line boats } \\ \text { on 1 January 1991 }\end{array} & \begin{array}{c}\text { Hook-and-line } \\ \text { quota share on } \\ \text { 1 September 2006 }\end{array} \\ \text { Cod } & 2.18 \% & 17.50 \% \\ \text { Haddock } & 0.55 \% & 14.67 \% \\ \text { Saithe } & 0.81 \% & 7.32 \% \\ \text { Wolffish } & \text { No TAC } & 38.52 \% \\ \text { Redfish } & \text { 0\% } & 0.59 \% \\ \text { Tusk } & \text { No TAC } & 12.59 \% \\ \text { Ling } & \text { No TAC } & 11.49 \%\end{array}$

These quota entitlements for hook-and-line boats had to be taken from other fishing vessels utilising the same exploitable marine stocks, i.e., primarily from vessels with quota shares (Gretarsson, H. 2010, 313).

\subsection{Main judgements}

Primarily two court cases are most important regarding the legality of the allocation of harvest rights in Iceland: the Fishing Permit Case of 1998 and the Vatneyri Case of 2000. In this regard it is also necessary to discuss the views of the United Nations' Human Rights Committee in the Fagrimuli Case of 2007.

First, the Supreme Court of Iceland's Fishing Permit judgement must be covered, cf. SCR 1998, 4076. The facts of the case were that the appellant had applied to the Ministry of Fisheries at the end of 1996 for a general fishing permit for commercial purposes and a catch quota in certain species. His application was rejected on the grounds that he did not own a fishing vessel falling under par. 1 of Article 5 of FMA, which was then in force.

This provision stipulated that only vessels having received general fishing permits according to Art. 4 and 10 of Act No. $3 / 1988$ on Fisheries Management 1988-1990, which had not been permanently decommissioned, were eligible for general commercial fishing permits. Lines 2 and 3 of the provision related to small boats and hook-andline boats. The provision had the effect that owners of new fishing vessel could not take part in commercial fisheries unless another vessel, of comparable effort capacity, was scrapped. ${ }^{26}$

In the court's opinion, the legal effect of the provision was to bind the general commercial fishing permits with ownership of vessels that were fishing in the early 1980 s or had replaced such vessels. It followed from this that the only persons having an opportunity to fish commercially were those who had received a right to do so as a result of private ownership, either by themselves or through purchase, inheritance or other transfer. The court invalidated the ministry's rejection on the grounds that the then-valid Article 5 of FMA conflicted with the principle of equality before the law 
under Article 65 of the Constitution, and the considerations of equality that had to be taken into account when limiting the freedom of employment. ${ }^{27}$

The facts of the Vatneyri Case were that the crew of the Vatneyri BA 238 engaged in cod fisheries in January 1999 without any catch quota. The vessel's skipper and the director of the company owning the vessel were prosecuted for violating FMA. The District Court dismissed the charges against them, on the grounds that the allocation of quota entitlements violated the Constitution's rule of equality before the law, cf. the Supreme Court's Fishing Permit judgement from 1998. The majority of the Supreme Court, on the other hand, deemed provisions regarding allocation of quota entitlements to be constitutionally valid and found the accused guilty, cf. SCR 2000, 1534 (Case no. 12/2000).

The arguments of the Supreme Court's majority opinion in the case were laid down in Section VI of the judgement. It was deemed that the division of quota entitlements for demersal species was principally based on the catch experience of individual vessels. Accordingly, those possessing quota entitlements had generally acquired this right on the basis of the catch experience of vessels in their ownership during a certain period, or derived their right from the catch experience of others owning such vessels. Although the legislature could have selected other alternatives in this regard, it was deemed that this legislative choice accorded with the Constitution's fundamental rule on equality before the law.

The facts of the Fagrimuli Case were that Erlingur Sveinn Haraldsson and Örn Snævar Sveinsson worked as fishermen on fishing vessels in the period 1 November 1980 to 31 October 1983 . One of them was the skipper and the other a boatswain. A private limited company that they owned, Fagrimuli, bought a fishing vessel in March 1998. No quota entitlements accompanied the vessel. The operations of Fagrimuli went poorly, and in September 2001 they engaged in commercial fisheries of cod, haddock, wolffish and plaice without sufficient catch quota. They were charged with violating FMA, and they based their defence, in part, on the argument that the allocation of quota shares violated the Constitution's rule on equality before the law and its provisions on freedom of employment. They were convicted under FMA in the Supreme Court of Iceland, with reference to the Supreme Court's judgement in the Vatneyri case, cf. SCR. 2003, 1176 (Case no. 473/2002).

The two fishermen filed a communication to the United Nations' Human Rights Committee. ${ }^{28}$ Their communication before the committee was based on the argument that the allocation of quota entitlements had created a privileged group on subjective grounds, and this contravened the rule of equality before the law in the UN Covenant on Civil and Political Rights, cf. Article 26 of the Covenant. The premise of the communication was that the allocation of quota entitlements had changed little since 1984 , and this violated the declaration of the act that fisheries resources were the common property of the Icelandic nation. ${ }^{29}$

The majority of the Human Rights Committee (12 of 18 committee members) used as a foundation that the allocation of quota entitlements was based on the fishing experience of fishing vessel operators during the period 1 November 1980 to 31 
October 1983. The committee deemed that quota entitlements had gradually become rights of non-expiring transferable value. No new party could obtain quota entitlements except by purchasing them from those who had got them initially or those that had replaced them. The committee deemed this to be unreasonable, with respect to the declaration it thought could be found in FMA, i.e., that the fishing grounds around Iceland were the common property of the Icelandic nation. ${ }^{30}$

\section{Allocation of harvest rights in Norwegian fisheries}

3.1 Exclusive fishing zone and economic and social background of commercial fisheries

In accordance with provisions of Act No. 91/1976 on the Norwegian Economic Zone, the EEZ of Norway was extended to 200 nautical miles, based on specified baseline points. Together, the territorial sea and the EEZ area ${ }^{31,}$ - encompasses approximately 1.2 million $\mathrm{km}^{2}$ but Norway is also responsible for two fishing zones around Spitzbergen and Jan Mayen that together amount to more than 1 million $\mathrm{km}^{2}$. (Hersoug, B. 2005, 38; OECD 2006, 224; Norwegian Ministry of Fisheries and Coastal Affairs 2007, 5).

Norwegian fishing banks are among the most productive in the world. Since 1985 the annual total catch of the Norwegian fleet has varied from approximately 1.5 million Mt. to 2.8 million Mt. (Fiskeridirektoratet 2011a, 15-16). The most valuable exploitable marine stocks are three demersal species in the Barents Sea that are found north of $62^{\circ} \mathrm{N}$ (Northeast Arctic cod, Northeast Arctic haddock and saithe) and four pelagic species (Atlanto-Scandian herring, mackerel, capelin in the Barents Sea and North Sea herring). ${ }^{32}$ Of these stocks, only saithe stays solely within the Norwegian EEZ, meaning that approximately $90 \%$ of the total catches are based on shared stocks, where the management responsibility is shared with Russia ${ }^{33}$, the $\mathrm{EU}^{34}$, Iceland, the Faroe Islands and Greenland. ${ }^{35}$

For the past two decades the seafood industry's ${ }^{36}$ contribution to Norwegian GDP has been relatively small; it was $0.5 \%$ in 1990 and $0.7 \%$ in 2006 (OECD 2006, 233; OECD 2011, 31), while the export value of seafood products has been higher, for example, in 1990 it was 6\% of the total exports, and in 2009 the same figure was 5.8\% (OECD 2006, 224; Norwegian Ministry of Fisheries and Coastal Affairs 2010, 7; OECD 2011, 31). Altogether 10,200 fishermen engaged in commercial fishing as their sole occupation in 2009, but in 1990 there were twice as many (Norwegian Ministry of Fisheries and Coastal Affairs 2010, 9). Prior to the expansion of the Norwegian oil industry in the 1970 s and onwards, the seafood industry played a bigger role in the national economy (OECD 2006, 222-225).

The moderate economic significance of marine fisheries does not change the fact that they are relatively important in Norwegian politics, mainly due to the role of the industry in providing jobs and ensuring settlement along the coast of western and northern Norway. Information on political and geographical points is therefore of some importance in understanding the structure of the Norwegian fisheries management system and the legal basis on which it rests.

Only a few of Norway's 19 counties have considerable stakes in commercial 
fisheries. Thus, the economic significance of fisheries is considerable in the three northernmost counties (Finnmark, Troms and Nordland) but its proportional significance is somewhat less in the west coast's southern counties (Møre and Romsdal, Sogn and Fjordane Hordaland and Rogaland). In counties other than these seven, commercial fisheries has much smaller economic significance.

Traditionally, the vast majority of coastal vessels have operated from the three northernmost counties. The same goes for trawlers having concessions in the Northeast Arctic cod stock. This means that vessels that operate from these three counties catch the bulk of the demersal catches. Pelagic fisheries are more important in the west coast's southern counties, for purse seiners have mostly operated from there. ${ }^{37}$

This divided importance of fisheries has in various ways affected the passage of acts and regulations on fisheries management in Norway. Thus, emphasis is placed on holding the level of employment high in fisheries in the northern counties in order to avoid disruption of settlement.

\subsection{Main rules of the Norwegian quota system}

For the most part Norwegian fisheries legislation builds, on one hand, on general laws on fisheries management and, on the other, on laws on the rights of particular parties to participate in commercial fisheries. The legislation in force on the former point is Act No. 37/2008 on the Management of Wild Living Marine Resources (MRA) ${ }^{38}$ and, regarding the latter, Act No. 15/1999 on the Right to Participate in Commercial Fisheries (Participation Act). ${ }^{39}$ To simplify the matter one can say that the MRA sets forth an arrangement on how much should be caught, as well as where and in which manner fisheries should be conducted, while the Participation Act stipulates who shall be able to conduct commercial fishing.

In essence, the effect of these two statutes is that few substantive rules on the quota system are stipulated in acts since extensive authority is delegated to the government ${ }^{40}$ to manage commercial fisheries with regulations. This basically means that the Norwegian government has, as a matter of law, broad discretion to manage fisheries. In spite of this the most important stakeholder in Norwegian fisheries, the Norwegian Fishermen's Association $(\mathrm{NFA})^{41}$, has been quite influential in the policy making process, cf. below.

The main substantive rules of the Norwegian quota system are as follows:

i) The wild living marine resources belong to Norwegian society as a whole, cf. Art. 2 of MRA. ${ }^{42}$ There is strong political resistance to any movement to consider the resource as belonging to private parties, even though concessions, fishing permits and fishing quotas are in the hands of active fishers (OECD 2006, 251252 and 256; Hersoug, B. 2005, 1-3).

ii) The Participation Act regulates the number of vessels that can join the various fisheries, and in principle the act stipulates a twofold model. On one hand, there are so-called concessions (licenses granted for an unlimited time-span) and, on the other, annual fishing permits (permits limited to one year at a time). ${ }^{43}$ Concessions and fishing permits are participation rights in the fisheries and are 
linked to vessels and individuals. The requirements for owning an active fishing vessel include that the individuals operating them shall be active fisherman. ${ }^{44}$ The main rule is that a fisherman is deemed to be active if he has engaged in commercial fishing for at least three of the last five years. ${ }^{45}$

iii) The Norwegian fleet has for quite a long time been divided into certain vessel groups. In order to simplify the picture, one can say that the fleet consists of offshore vessels and coastal vessels. Trawlers and purse seiners belong to the offshore fleet (these vessel groups are obliged to have concessions), while vessels using conventional gear (i.e., long-lines, nets and jigging) belong to the coastal fleet (this vessel group is now obliged to have an annual fishing permit). These main vessel groups are then divided into sub-vessel groups, varying from one fish stock to the next.

iv) Since 1990 it has been acknowledged that all vessel groups have to be subject to license and quota regulation in the most valuable fisheries. This has had the effect that almost all vessel groups are a 'closed shop', i.e., no new member can enter them unless fulfilling all the conditions pertaining to fishing licenses, meaning that a party usually has to buy a vessel from another participant in the fisheries in order to start commercial fishing.

v) When international negotiations on annual TACs have been concluded, the Ministry of Fisheries and Coastal Affairs decides how the TACs for the following year should be allocated, and what other rules should apply for managing commercial fisheries. ${ }^{46}$ Prior to this decision making, the stakeholders in the fishing industry and officials of the Fisheries Directorate have had an advisory meeting for fisheries regulations ${ }^{47}$, but before the commencement of this advisory meeting, NFA has usually submitted proposals on how TACs should be distributed, and what other rules should apply for managing the fisheries.

vi) Of course, NFA's proposals on allocations of quotas are not legally binding. However, they have usually been more or less upheld when the ministry promulgates regulations on the matter.

vii) Since 1996 individual vessel owners, in certain vessel groups, have been permitted to merge their quotas with quotas of other vessels within the same vessel group. ${ }^{48}$ These rules were changed in 2004 and 2005, effectively applying the rules to more vessel groups and ensuring more freedom for individual vessel owners to merge their quotas with others within the same vessel group or, as the case may be, within the same sub-vessel group. These regulations were changed again in 2007 , and the current rules on the matter are quite complicated. ${ }^{49}$

viii) In order to simplify the matter, one can say that the current principle is that one vessel owner can, within certain maximum limits, merge quotas from other vessels to his own. The vessel, that has no quota left, has to be scrapped. Quota that is transferred in this way is valid for twenty years and after that period it will be allocated equally to every vessel that belongs to the vessel group or the sub-vessel group. Various kinds of other conditions apply for this transaction of quota to take place, for example, there are certain regional restrictions, i.e. provisions that 
provide that vessels and quota cannot easily be moved from the northernmost regions to the southern part of the country. ${ }^{50}$ In some vessel groups the buyer of the 'quota' does not get it all, since some proportion of it will be allocated equally between all vessels within the relevant vessel group or sub-vessel group. ${ }^{51}$

\subsection{Development of rules on the allocation of harvest rights}

When the history of Norwegian fisheries management is examined, one has to bear in mind that as early as the 1930s limitations to conduct fisheries with trawlers ${ }^{52}$ were imposed, and in 1973 a new system was adopted to manage pelagic fisheries of the purse seine fleet, a system that was stricter than the permit system for trawlers, since no new vessel was allowed to enter the purse seine fleet, unless another vessel, with similar capacity, would be decommissioned (closed-shop system).

Even though most could concur that it was a necessity in the late 1970s and the 1980s to allocate individual annual catch opportunities to vessels with high-effort capacity, such as the trawlers and the purse seiners, not many could foresee that the same would eventually apply to the coastal fleet; for example, it was stipulated in the original agreement on the Norwegian-Russian Fisheries Commission that the coastal fleet could continue to catch Northeast Arctic cod even though the fleet had reached its anticipated quota limit. ${ }^{53}$ The Russians requested this to be halted in 1983, and in 1985 the overfishing of the coastal fleet was stopped. In 1986-1988 the coastal fleet was not able to catch its entire quota (Hersoug, B. 2005, 139).

In 1989 the TAC in Northeast Arctic cod was reduced to 300 thousand Mt., compared to 451 thousand Mt. the previous year. The coastal fleet's catches of the Northeast Arctic cod had to be stopped on the 18th of April 1989 since the fleet had already caught its quota. Later in 1989, a report was published by scientists, indicating that the fishing mortality of the cod stock would need to be seriously reduced. This was accepted by the Norwegian-Russian Fisheries Commission, and the overall TAC for 1990 was set at 160 thousand Mt. The consequence of this reduction was that economic prospects for most fleet segments were dim (Hersoug, B. 2005, 140-141).

This cod crisis in 1989-1990 forced the fishing industry and the government to come up with solutions on how to allocate scarce fishing opportunities in cod among all the different vessel groups. This process moved to other fish stocks in the 1990s and the first decade of the 21st century. Hence, the open access regime to usage of the resource since 1973 has, little by little, come to an end. This is thought to be controversial, at least in some academic quarters (Hersoug, B. 2005, 1-6 and 245-260; Skogvang, S. (2010), 212, 222-227 and 243).

The role of NFA has been significant when it comes to allocation of quota. The organisation's annual general meetings have passed resolutions every few years regarding "allocation keys". By this the fishing industry recommends how quotas should be divided among vessel groups, sub-vessel groups and individual vessels. The most significant resolutions in this regard are from 1989, 1994, 2001 and 2007. Basically the first resolution dealt only with allocation of quota in the Northeast Arctic cod stock, but later resolutions dealt with other important fish stocks as well. 


\subsubsection{Main rules on allocating quota among vessel groups}

In 1990-1994 an allocation key for Northeast Arctic cod was in place that prescribed that the coastal fleet would get $65 \%-80 \%$ of the Norwegian TAC, while the trawler fleet got 20\%-35\%. ${ }^{54}$ During the NFA's general meeting in 1994, it was agreed that the coastal fleet would be able to catch $67 \%-72 \%$ of the Norwegian TAC in the stock, while the trawler fleet would get 28\%-33\%. Below a certain level the coastal fleet would get a higher percentage of the TAC, while the trawler fleet would get $33 \%$ if the overall Norwegian TAC would at least reach 330,000 Mt. These principles continued to apply under the NFA's resolutions in 2001 and 2007 (Fiskeridirektoratet 2001, 11; Fiskeridirektoratet 2008, 4-5).

According to NFA's resolution in 1994 the trawler fleet was supposed to get 39\% of the TAC in haddock and the coastal fleet $61 \%$. This was changed in 2001 so the trawler fleet would get $38 \%$ of the TAC and the Coastal fleet $62 \%$. This share ratio between the trawlers and the coastal fleet has been applied since 2008 .

The resolution of NFA in 1994 on how TAC in saithe should be divided was not as clearcut as for cod and haddock. In 2001 the NFA proposed that the coastal fleet would get $38 \%$ of the TAC in saithe, trawlers $37 \%$ and seiners (not purse seiners) $25 \%$. Since then this division has been applied.

Allocation keys in pelagic stocks, agreed upon within the NFA, grew in importance in the 1990s when it became evident that the biggest stock, Atlanto-Scandian herring had regained its previous productivity after the stock collapsed in the late 1960s. Under NFA's resolution in 1994, the purse seiners acquired the highest share of the quota in Atlanto-Scandian herring stock if the TAC was above certain limits, but below them the coastal fleet's proportion would increase. In 1995-2001 the purse seiners usually got around $60 \%$ of the TAC; the coastal fleet received a little bit more than 30\% and trawlers approximately 9\%. The allocation key was changed in 2002 in order to increase the share of the coastal fleet, and this continued in 2007. In the period 2008-2010 the purse seiners received 52\% of the TAC, the coastal fleet $37 \%$ and the trawler fleet $11 \% .^{55}$

According to NFA's resolution in 1994, the TAC in mackerel was distributed among purse seiners, the coastal fleet and trawlers. Trawlers were supposed to acquire $2 \%$ of the TAC, coastal vessels were allowed to catch mackerel until the vessel group had reached 20,000 Mt., and the purse seiners were to get the rest of the TAC. In the period 1995-2001 the purse seiners got $79-89 \%$ of the TAC, but this share was decreased under NFA's resolution in 2001, since according to it, trawlers were to get $3.5 \%$ of the TAC, the coastal fleet $18.5 \%$ (never lower than 25,000 Mt.) and purse seiners the rest. These criteria have been applied since $2008 .^{56}$

The purse seine fleet has also received the bulk of the quota in herring south of $62^{\circ} \mathrm{N}$ and in the capelin stock of the Barents Sea. The division of these two stocks will not be explained any further.

In spite of the foregoing it has to be emphasised that NFA's resolutions are not legally binding even though they are usually accepted by the government. From time to time the government has deviated from NFA's proposals; for instance, the govern- 
ment has issued research and recreational quotas since 2004 in Northeast Arctic cod, and therefore diminished the portion that is available for commercial fishers. In 1998 the government also deviated from NFA's resolutions when allocating quota in the pelagic fish stocks of Atlanto-Scandian herring and mackerel, so that the coastal fleet acquired a higher percentage of the TAC than was provided for in NFA's resolution on the matter (Hersoug, B. 2005, 147).

\subsubsection{Main rules on allocating quota among sub-vessel groups}

There have been various types of vessels within each vessel group, for example, in terms of length, effort capacity and cargo capacity. This diversity has called for some sub-division of each vessel group, creating so-called 'sub-vessel groups'. There can be many sub-vessel groups in each vessel group. Normally, vessels that have similar effort capacity are grouped together. The proportion each group has in the TAC varies between sub-vessel groups.

When the quota in Northeast Arctic cod was initially divided in 1976 among trawlers above 250 GRT, the fleet was divided into three sub-vessel groups, (1) fresh fish trawlers, (2) trawlers processing salted fish and (3) factory trawlers. In accordance with certain rules on how to calculate the proportion of each sub-vessel group and individual vessels (so-called base quota and quota factor), the factory trawlers got the highest proportion of the vessel group quota, followed by trawlers processing salted fish and fresh fish trawlers. Little by little other trawlers' advantage over the fresh fish trawlers was abolished ${ }^{57}$, and since 1990 trawlers with cod concessions have had an equal share in their vessel group quota in Northeast Arctic cod.

The initial principles on how to divide participation rights and quota among vessels in the coastal fleet in the Northeast Arctic cod stock were stipulated by a regulation in December 1989, applying in $1990 . .^{58}$ The coastal fleet was divided into two, the closed group (initially called Group I) and the open group (initially called Group II). To begin with, there were 3,534 vessels in the closed group and 4,172 in the open group (Hersoug, B. 2005, 114-115). The closed group got 80\% of the coastal fleet quota and the open group $20 \%$. Rules on allocation of harvest rights in the coastal fleet were amended in 1991-1994; for instance, more vessels were allowed to enter the closed group than was anticipated in 1990 (Hersoug, B. 2005, 116-118 and 120).

In 1995 it was decided that vessels, 28 metres and longer, were not any longer part of the closed or open group of the coastal fleet. Since then, these long-liners have been a special sub-vessel group. They have for some time now received approximately $13 \%$ of the entire coastal fleet quota in Northeast Arctic cod, while the closed group of the coastal fleet has received around $77 \%$, and the open group has received around $10 \%$ (Fiskeridirektoratet 2001, 21; Fiskeridirektoratet 2008, 5 and 17).

The so-called Finnmark model (Hersoug, B. 2005, 120-121; OECD 2006, 254) was introduced in 2001 in the coastal fleet, having the effect that the closed group of the coastal fleet was divided into four sub-vessel groups. This obviously affected how quota was divided among vessels in the closed group, particularly in the Northeast Arctic cod stock. ${ }^{59}$

There have not been any significant sub-vessel groups within the purse seine fleet. 
3.3.3 Main rules on allocating quota between individual vessels

The main rule on allocating quota among individual participants in a vessel group or sub-vessel group has been based on equal shares (all vessels get the same quota) ${ }^{60}$ or some variation of this principle, namely, a combination of equal sharing and effort capacity of individual vessels. ${ }^{61}$ The catch history of each vessel has played an important role in determining the vessel group's or the sub-vessel group's proportion of the TAC. Criteria other than catch history have also been applicable, for instance, to ensure certain regional policy goals.

The annual quota of vessel groups like trawlers and purse seiners is usually divided among all participating vessels, meaning that there is a fixed individual vessel quota for each fish stock (Individual Vessel Quotas or IVQs). This principle also now applies to some sub-vessel groups in the coastal fleet, such as the long-liners (applies for all fish stocks) and the three largest fleet segments within the closed group (applies only for the Northeast Arctic cod stock management).

Within the closed group of the coastal fleet the main rule is to allocate fishing opportunities by issuing a so-called maximum quota, where individual vessels have, on the one hand, a guaranteed quota and, on the other, a maximum quota. The latter quota is higher than the former (this is called overregulation). ${ }^{62}$ If a sub-vessel group has not reached its quota limits, individual vessels can catch as much as they can within their individual maximum quota limits. However, if vessels belonging to the sub-vessel group have caught more than is allowed, individual vessels can, from that point in time, only catch according to their guaranteed quota.

\subsection{Main judgements}

Fisheries management in Norway is based on the cooperative management of governmental and private parties. Consequently, there are not many judicial cases that have dealt with the foundation of the system. It can be said that older case law indicated that the government had wide discretion to change the rules on fisheries management even though such changes involved financial costs for individual fishing vessel owners.

For instance, it was held in a judgement of the Norwegian Supreme Court, 1993, $578,{ }^{63}$ that in the 1980 s the government was able to reduce the quota proportion of factory trawlers and trawlers processing salted fish in the trawler vessel group. These measures were deemed to contravene neither fundamental rules of administrative law nor the property rights provision of the Norwegian Constitution. ${ }^{64}$

In another judgement of the Norwegian Supreme Court, 1995, 955, ${ }^{65}$ it was held to be valid that the government could exclude certain individuals from participating in the closed group of the coastal fleet in cod fisheries in 1990 although they had in the preceding years been operating a boat for commercial purposes. This conclusion was based on the point that the parties had not fulfilled the relevant catch history criteria. Hence, the parties were denied any right to catch cod in the closed group in 1990 on sufficient legal grounds. ${ }^{66}$

On 7 January 2011 the City Court of Oslo (first judicial level of three) rendered a judgement ${ }^{67}$, holding that the government had violated a fundamental rule of the 
Norwegian Constitution forbidding acts to apply retroactively. The facts of the case were that in 2005 a regulation was issued promulgating that fishing vessel owners, including those of long-liners longer than 28 metres, could merge the quotas of other vessel owners with their own, and that the purchased quota would be valid indefinitely. On this basis, an owner of a long-liner in the coastal fleet bought two other vessels belonging to the same sub-vessel group. The purchased vessels were scrapped and their quotas merged with the buyer's boat.

Shortly thereafter a new government came to power, and in the fall of 2005, it was forbidden to purchase vessels for the purpose of obtaining their quotas. This ban was abolished in the summer of $2007 .{ }^{68}$ On that occasion the rule was set that those who had already merged quotas with their vessels could only keep the purchased quotas for 25 years as of the start of 2008. This change of regulation meant that the buyer of the two vessels could now expect to possess the 'merged quotas' until 2032 instead of having them indefinitely. The judgement held that this new arrangement was onerous for the fishing vessel owner in question, and that Article 97 of the Norwegian Constitution, banning retroactive acts, had been violated. ${ }^{69}$

\section{Comparison}

Although conditions in Iceland and Norway have been and will be dissimilar, it can be asserted that the most important reason that the states adopted quota systems to manage fisheries was that other approaches to assuring protection of the resource proved unsatisfactory. Since commercial fisheries are important in the two states, they also had to create a framework for increasing the national efficiency of commercial fisheries. This has been done by providing the industry with considerable involvement in determining how it will be most advantageous to utilise the resource. In Iceland this has mostly been done by creating a market for individual and transferable vessel quotas, while in Norway this has been done by providing the industry with a broad right of intervention regarding which rules shall be enforced on fisheries management, including how the harvest rights shall be divided.

The allocation of harvest rights in the two states can be compared as follows:

i) In both states, harvest rights have mainly been allocated to active fishermen. This means that the original shaping of harvest rights has taken into account historical usage of the resource. In this way the initial allocation of the harvest rights has protected the professional interest of those that have already participated in the fisheries, meaning that professional fishers receive fishing permits initially and also the accompanying quotas linked to these permits. Despite this the original allocation of harvest rights is not engraved in stone since rules on these matters are dynamic and contingent on various amendments by the legislature and government.

ii) It is noteworthy that, for the most part, rules on the allocation of harvest rights are based on an act in Iceland, while in Norway the legislature has delegated considerable power to the executive power to decide rules on these matters. Despite the legislature's delegation of power in Norway, the industry there probably has 
greater influence on how harvest rights are divided than in Iceland. There is a long history of co-operative management of fisheries by private and governmental parties in Norway. This in part entails that in all major respects the industry itself determines how a quota shall be divided between vessel groups, sub-vessel groups and individual fishers.

iii) The legal validity of the fundamental rules on the allocation of harvest rights has been tested more in Iceland than in Norway. In 1998 the Supreme Court of Iceland held that the allocation of general fishing permits for commercial purposes violated the fundamental rules on equality before the law and freedom of employment. A majority of the United Nations' Human Rights Committee deemed that the allocation of quota shares violated the general rule of equality of the UN Covenant on Civil and Political Rights. Both of these findings were based on the premises that the allocation of harvest rights in the Icelandic system rested on the economic activity of professional fishers in the early 1980s, and since then these criteria had changed little or not at all. As related in Section 2.3, these premises do not stand up under examination, and this should weaken the precedence value of these two findings.

iv) Although transfers of individual vessel quotas are allowed in Iceland, various aspects of the legal structure of the quota system tend to limit the rights of the holders of the harvest rights. Here it is important to note that Article 1 of FMA states that the allocation of harvest rights provided for by the Act endows individual parties with neither rights of ownership nor irrevocable control over harvest rights. It is also necessary to bear in mind that part of the harvest rights for several important exploitable marine stocks have been reallocated, not least for the benefit of the owners of hook-and-line boats.

v) Harvest rights in Norway are in many ways based on annual regulations, not on acts. Generally, this would tend to weaken the legal status of harvest rights; however, it is not certain that this is actually the case. When it is taken into consideration how much weight resolutions of the NFA have had for the past 20 years on the allocation of harvest rights, it can be supposed that the perspectives of legitimate expectations and careful administrative practices ensure holders of harvest rights in Norway a reasonable legal protection. 


\section{Notes}

The author is a researcher in law at the University of Iceland's Institute of Law and a Ph.D. student at the University of Iceland's Faculty of Law. The author's position as a researcher in law has been funded with two collaboration agreements of the University of Iceland's Institute of Law and the Federation of Icelandic Fishing Vessel Owners. In the spring of 2009, the author received a grant for his Ph.D. studies in the amount of ISK 1 million from the Bjarni Benediktsson Research Grant Fund.

1 "Strong centralised power" means that the regulatory power in the field of fisheries management resides in institutions (i.e., the legislative and executive powers) that can alone set rules on the matter, and the rules cover all the coastal state's citizens and ocean area where the citizens are permitted to conduct commercial fisheries.

2 According to international law they are also able to manage fisheries of their flag fishing vessels beyond the limits of their EFZ or EEZ.

3 In this article the concept "harvest rights" will be used broadly, i.e., it refers to conditions that must be fulfilled by an individual or an individual entity to engage in commercial fisheries. Normally these conditions relate to possession of relevant fishing permits and quotas.

4 This means, inter alia, that issues related to fishing rights of owners of land, adjacent to the sea, in both Iceland and Norway, will not be discussed. The same goes for claims that are based on indigenous fishing rights in Norway. Consequently, the article is primarily focused on how commercial harvest rights have been allocated in the two countries since 1990.

5 It has to be underlined that no discussion will be devoted to how these systems might be altered in the future, i.e., the methodological emphasis is on 'lex lata' not on 'de lege ferenda'.

6 This extension was based on provisions of Act No. 44/1948 on Scientific Protection of the Fishing Banks on the Continental Shelf. Extensions of the Icelandic EFZ from 1903-1975 are illustrated in Arnason, R. (1995), 101.

7 See relevant provisions of Act No. 41/1979 on Territorial Limits, an Economic Zone and the Continental Shelf

$8 \quad$ FMA came into force on the 18th of May 1990 but took effect on the 1st January 1991.

9 Since the 1st September 1991 the fishing year has been designated as running from the first of September to the thirty-first of August.

10 Judgement of the Supreme Court of 3 December 1998 in the Case Valdimar Johannesson versus the Icelandic State (Case No. 145/1998, Supreme Court Records (SCR) for 1998, p. 4076). This case is discussed further in section 2.4.

11 These provisions primarily pertain to the requirement that the owner shall be an Icelandic citizen or Icelandic legal entity fulfilling the provisions of the Act No. 34/1991 on Investment by Foreign Parties in Industrial Operations.

12 The effect of this arrangement can be explained with a simple example. The owner of vessel A has a 10\% quota share for species X. During fishing year Y, the TAC of X is determined to be 100,000 Mt. Vessel A is therefore permitted to catch $10,000 \mathrm{Mt}$. of $\mathrm{X}$ during fishing year Y, i.e. A's catch quota is $10,000 \mathrm{Mt}$. in the stock X.

13 See Article 72 of the Icelandic Constitution.

14 See Article 1 of Protocol 1 of the European Convention of Human Rights.

15 These property rights issues are for example discussed in Gretarsson, H. 2011, 116-128 and 145-149; Views, adopted by the Human Rights Committe on 24 October 2007, concerning communication No. 1306/2004 (2008), pp. 11-15; Gauksdottir, G. 2006; Magnusson, S. 1997.

16 This complicated development is described in Gretarsson, H. (2010), 306-309.

17 As will be mentioned later, this arrangement was abandoned when the fishing effort system of the hook-andline boats continued on the basis of act that amended FMA, cf. Act No. 87/1994.

18 These stocks are as follows: plaice (quota share allocated in 1991), wolffish (1996), witch (1996), dab (1997), long rough dab (1997), lemon sole (1999), ling (2001), tusk (2001) and anglerfish (2001).

19 See current par. 1 of Article 9 of FMA.

20 These stocks are as follows: redfish in the Reykjanes Ridge (quota share allocated in 1997), shrimp in the Flemish Cap (1997), Northeast Arctic Cod (1999), Atlanto-Scandian herring (2002) and blue whiting (2002).

21 See current par. 2 of Article 5 of Act No. 151/1996 on Fishing beyond Iceland's Exclusive Fishing Zone and Gretarsson, H. 2011, 69-74.

22 These special allocations are discussed further in Gretarsson, H. 2011, 48-49; Gretarsson, H. 2010, 312.

23 This can be illustrated by an example: The owner of vessel A has a $10 \%$ quota share for the stock X. During fishing year Y, the TAC of X is set at 125,000 Mt. According to the main rules of the system, vessel A would be permitted to catch 12,500 Mt. of X during fishing year Y. However, due to the fishing rights of the hook- 
and-line boats and special allocations, 25,000 Mt. are deducted from the TAC before it is divided among vessels with quota shares in $\mathrm{X}$. Hence, vessel A will be permitted to catch 10,000 Mt. of X during fishing year $Y$.

24 The provisions of this act provided for some amendment of FMA.

25 Source: Parliament reg. Section A, 2006-2007, p. 1403.

26 Possession of a vessel with general commercial fishing permit was usually not sufficient to start professional fishing since it was also necessary to have quota entitlements or other fishing rights (such as effort days for hook-and-line boats) linked to a vessel.

27 See Article 75 of the Icelandic Constitution.

28 Views of the United Nations' Human Rights Committee of 24 October 2007 in communication No. 1306/2004 of Erlingur Sveinn Haraldsson and Örn Snævar Sveinsson versus the Icelandic State.

29 In January 2007 the Icelandic State put forward its observation on the merits of the communication. In that observation the State did not dispute the understanding of the parties commencing the communication regarding the substance of the allocation rules. Also, the State did not deal with the substantive gist of the declaration that exploitable marine stocks on Iceland's fishing grounds were the common property of the Icelandic nation.

$30 \quad$ Line 1 of Article 1 of FMA states: "Exploitable marine stocks on Iceland's fishing grounds are the common property of the Icelandic nation." The text of the provision indicates that it is the exploitable marine stocks as such that are the common property of the Icelandic nation, not the fishing grounds. There has been general solidarity in scholarly writings in Icelandic law that the declaration cannot create a property right, for either the nation or the State, cf. Gretarsson, H. 2011, 29-30; Views, adopted by the Human Rights Committe on 24 October 2007, concerning communication No. 1306/2004 2008, pp. 12-13; Magnusson, S. 1997, p. 65.

31 Following the extension of the Norwegian EEZ, there was a so-called Grey Zone $\left(175,000 \mathrm{~km}^{2}\right)$ within the claimed Norwegian EEZ since there was a disagreement between Norway and Russia (former Soviet Union) on how to delimit this area. The two coastal states made an interim agreement that was valid until the matter was finally settled by an agreement made in September 2010.

32 On how catch value of the Norwegian fleet has developed since 1985, see Fiskeridirektoratet 2011a, 19-20. For the past ten years the Northeast Arctic cod stock and the Atlanto-Scandian herring have been the most valuable stocks, cf. Fiskeridirektoratet 2011a, 19 and 21-22.

33 For a long time Norwegians have collaborated to a great extent with Russians, for these states have for example managed fisheries of shared stocks like cod, haddock and capelin. The cooperation of the two coastal states takes place under the aegis of the Joint Norwegian-Russian Fisheries Commission, cf. Hønneland, G. 2007 and Norwegian Ministry of Fisheries and Coastal Affairs 2007, 10.

34 Norway's collaboration with the EU on these matters has a long history, for instance, when managing stocks like the mackerel and North Sea herring, see further Norwegian Fisheries Management (2007), p. 10.

35 The Norwegians have cooperated with Icelanders, Faroese and Greenlanders, for example, when managing stocks like the Atlanto-Scandian herring and the Icelandic capelin.

36 Including fish-farming products.

37 This description of the division of the fleet is based, among other things, on Fiskeridirektoratet 2011b, 24-32 and 50-64.

38 In Norwegian: Lov om forvaltning av viltlevande marine ressursar. An older act on these matters was Act No. 40/1983 on Saltwater Fisheries Management, (n. lov om saltvannsfiske m.v.).

39 In Norwegian: Lov om retten til å delta i fiske og fangst. An older act on these matters was the Act No. 57/1972 on the Right to Participate in Commercial Fisheries, (n. lov om Regulering av deltagelsen i fisket).

40 Ministry of Fisheries and Coastal Affairs stipulates regulations, while the Fisheries Directorate takes care of the day-to-day management of the fisheries.

41 In Norwegian: Norges Fiskarlag. Most special-interest organisations in the Norwegian fishing sector have representatives in NFA, for example, fishing vessel owners, the crew and so on. For the last 20 years some parties have withdrawn from Norges Fiskarlag; for some time an association has been operating called Norges Kystfiskarlag, which mainly protects the interests of coastal fishers, cf. Hersoug, B. 2005, 30.

42 As is carefully explained in preparation documents, this statement entails neither any state property right nor any other kind of property right, cf. Ot.prp. No. 20 (2007-2008), 40-42.

43 See Articles 4 and 21 of the Participation Act. Theoretically there is supposed to be a difference between these two, but in praxis the annual permits are renewed indefinitely, if the objective criteria are fulfilled each year, cf. OECD 2006, 231.

44 These rules apply when individuals own vessels in their own name as well as when legal entities are involved. An active fisherman has to own a majority of a legal entity and manage its operations. If these conditions are 
not fulfilled, the legal entity will lose the right to engage in commercial fisheries. In praxis the concept 'active fisherman' has also been applied to an individual that is not a member of the crew but is actively operating the business from shore.

45 If a license holder dies, the heirs have five years to become active fishermen, or else the license is cancelled, cf. Participation Act par. 2, art. 7.

46 These regulations are usually promulgated in December and apply for the following year.

47 The minutes of these meetings since 1993 are available on the homepage of the Norwegian Fisheries Directorate, http://www.fiskeridir.no/fiske-og-fangst/sakspapirer-referater (17 October 2011).

48 The rules applying to this matter, in the period 1984-2005, are explained in OECD 2006, 236-240.

49 See Forskrift No. 193/2005 om strukturkvoteordning mv. for havfiskeflåten (e. Regulation No. 193/2005 on Structure Quota for the Offshore Fleet) and Forskrift No. 1309/2003 om specielle kvoteordninger for kystfiskeflåten (e. Regulation No. 1309/2003 on Special Quota Arrangement for the Coastal Fleet).

50 See for example current Forskrift No. 193/2005 om strukturkvoteordning mv. for havfiskeflåten, art. 9.

51 See for example current Forskrift No. 1309/2003 om specielle kvoteordninger for kystfiskeflåten, art. 11.

52 See further Hersoug, B. 2005, 59-66. There were 11 trawlers active when these limitations started but due to various exceptions they increased in number.

53 This arrangement was based on the belief that the coastal fleet was more dependent on availability of the fish than the trawler fleet and that gear restrictions would be sufficient to keep their catch within their total quota limit. This proofed to be wrong, for example in 1981 the coastal fleet caught more than twice than was expected, cf. Hersoug, B. 2005, 139.

54 What percentage would apply depended on the TAC. The main rule was that if the TAC was low, the coastal fleet's proportion would increase but would decrease if the TAC increased, cf. Hersoug, B. 2005, 141.

55 These figures are based on relevant minutes from meetings of the Regulatory Advice Council and quota regulations imposed in this period.

56 Ibid.

57 This development is explained in more detail in the judgement of the Supreme Court of Norway, 1993, p. 578 (579), cf. section 3.4 .

58 See Forskrift No. 1193/1989 om adgang til å delta I fisket etter norsk arktisk torsk med konvensjonelle redskap nord for 62 N i 1990 (e. Regulation No. 1193/1989 on Participation Conditions of the Coastal Fleet in Catching Northeast Arctic Cod in 1990).

59 These sub-vessel group are now divided as follows: (1) Vessels under 11 metres in length that have altogether $27.69 \%$ of the cod quota of the closed group; (2) Vessels 11-14.99 metres long that have $26.68 \%$ of the cod quota of the closed group; (3) Vessels 15-20.99 metres long that have altogether 27.34\% of the cod quota of the closed group; (4) Vessels longer than 21 metres but having less cargo capacity than 500 cubic metres that have altogether $18.29 \%$ of the cod quota of the closed group.

60 This can be explained with an example: In a vessel group there are 100 vessels. The vessel group quota is $10,000 \mathrm{Mt}$. in stock A; hence each vessel gets a quota of $100 \mathrm{Mt}$. in the stock.

61 For example, the allocation of quota among purse seine vessels in most pelagic stocks has been based on somewhat complicated formulae that combines the principle of equal sharing and sharing according to each vessel's cargo capacity, cf. Ot.prp. No. 20 (2007-2008), p. 73.

62 This concept, overregulation, is explained in Hersoug, B. 2005, 118 and OECD 2006, 232-233.

63 Rt. 1993, 578.

64 This judgement is discussed further in Ot.prp. No. 20 (2007-2008), 71-72.

65 Rt. 1995, 955.

66 This judgement is discussed further in Skogvang, S. 2010, 228-229.

67 Judgement of the City Court of Oslo of 7 January 2011 in Case No. 10-091185TVI-OTIR/10.

68 The general rule was set that those purchasing vessels and merging quotas with another vessel shall keep the quota for 20 years, cf. point viii in section 3.2.

69 The Norwegian State has appealed the judgement. 


\section{References}

Arnason, R. and Runolfsson, B. (2001): "Initial Allocation of ITQs in the Icelandic Fisheries". Case studies on the allocation of transferable quota rights in fisheries. FAO Fisheries Technical Paper. No. 411. Shotton, R. (ed). Rome, pp. 24-31.

Arnason, R. (1997): "On the Icelandic ITQ System and its Consequences“. Property Rights in the fishing industry. Ed. Petursdottir, G. and Palsson, G. Fisheries Research Institute and Agricultural Economics Research Institute, Reykjavik, pp. 71-101.

Arnason, R. (1995): The Icelandic Fisheries Evolution and management of a fishing industry. Fishing News Books, Oxford.

Fiskeridirektoratet (2011a): Økonomiske og biologiske nøkkeltal frå dei norske fiskeria-År 2010. Fiskeridirektoratet, Bergen, available at http://www.fiskeridir.no/brosjyrer/statistiske-publikasjoner (17 October 2011).

Fiskeridirektoratet (2011b): Fiskefartøy og fiskarar, konsesjonar og arlige deltakaradgangar I 2010 (2011). Fiskeridirektoratet, Bergen, available at http://www.fiskeridir.no/brosjyrer/statistiske-publikasjoner (17 October 2011)

Fiskeridirektoratet (2008): Forslag til Forskrift om Regulering av Fisket etter Torsk, Hyse og Sei I 2008. Fiskeridirektoratet, Bergen, available at http://www.fiskeridir.no/fiske-og-fangst/sakspapirer-referater (17 October 2011).

Fiskeridirektoratet (2001): Referat fra Møte i Reguleringsradet 21. og 22. November 2001. Fiskeridirektoratet, Bergen, available at http://www.fiskeridir.no/fiske-og-fangst/sakspapirer-referater (17 October 2011)

Gauksdottir, G. (2006): "Eru aflaheimildir eign í skilningi 72. gr. stjskr?”.

Gudrúnarbók - Afmaclisrit til heidurs Gudrúnu Erlendsdóttur, 3. mai 2006. Reykjavik, pp. 249-275.

Gretarsson, H. (2011): Pjóðin og kvótinn: Um íslenska fiskveiðistjórnkerfið 1991-2010 og stjórnskipuleg álitaefni. Ritröð Lagastofnunar Háskóla Íslands Nr. 9. Bókaútgáfan Codex, Reykjavik.

Gretarsson, H. (2010): "Allocation of Demersal Harvest Rights in Iceland". Artic Review on Law and Politics. Gyldendal Akademisk, no. 2/2010, volume 1, Oslo, pp. 299-318.

Gretarsson, H. (2008): Réttarsaga fiskveiða frá landnámi til 1990. Ritröð Lagastofnunar Háskóla Íslands Nr. 6, Reykjavik.

Hersoug, B. (2005): Closing the Commons - Norwegian fisheries from open access to private property. Eburon, Delft.

Hønneland, G. (2007): Kvotekamp og kyststatssolidaritet: Norsk-russisk fiskeriforvaltning gjennom 30 år. Fagbokfarlaget, Bergen.

Islandsbanki Seafood Industry Team (2011): Iceland Seafood Market Report. Reykjavik, available at http://www.islandsbanki.is/english/seafood-industry/datamarket/\#publication (17 October 2011).

Iversen, A. et.al. (2011): Markeds- og verdikjedeanalyse - Fase 1 av prosjekted Value Proposition I nordisk marin sektor. Norden, Nordic Innovation, Oslo.

Magnusson, S. (1997): "Constitutional Property Protection and Transferable Fishing Quotas in Iceland". Property Rights in the fishing industry. Ed. Petursdottir, G. and Palsson, G. Fisheries Research Institute and Agricultural Economics Research Institute, Reykjavik, pp. 57-69.

Norwegian Ministry of Fisheries and Coastal Affairs (2010): Facts about Fisheries and Aquaculture 2010. Oslo, available at http://www.fisheries.no/Publications/ (17 October 2011).

Norwegian Ministry of Fisheries and Coastal Affairs (2007): Norwegian fisheries management. Oslo available at http://www.fisheries.no/Publications/ (17 October 2011).

OECD (2011): Fisheries Policy Reform - National Experiences. OECD, Paris.

OECD (2006): Using Market Mechanisms to Manage Fisheries - Smoothing the Path. OECD, Paris. Ot.prp. No. 20 (2007-2008). Oslo.

Runolfsson, B. (1999): "The Icelandic System of ITQs: Its Nature and Performance“. Individual Transferable Quotas in Theory and Practice. Ed. Arnason, Ragnar and Gissurarson, Hannes. The University of Iceland Press. Reykjavik, pp. 103-140.

Skogvang, S. (2010): ”Innføringen av fartøykvoter for torsk I kystfiskeflåten I 1990“. Natur, Rett, Historie. Bull, K. (ed.), Akademisk publisering, Oslo, pp. 210-245.

The Icelandic Parliament Registry.

Views, adopted by the Human Rights Committe on 24 October 2007, concerning communication No. 1306/2004 (2008). The reply of the Icelandic government to the Human Rights Committee, available at http://eng.sjavarutvegsraduneyti.is/news-and-articles/nr/9306 (17 October 2011). 